Nig. J. Biotech. Vol. 36 (2) : $21-26$ (Dec 2019)

ISSN: 01891731

Available online at

http://www.ajol.info/index.php/njb/index

and www.biotechsocietynigeria.org

DOI: https://dx.doi.org/10.4314/njb.v36i2.3

\title{
Mycoflora and Aflatoxin Levels in Stale Retailed Pepper Sold in Abeokuta Nigeria
}

\author{
${ }^{1}$ Oni E. 0., ${ }^{2}$ Adebajo L.0. ${ }^{1}$ Badmos A. 0., ${ }^{1}$ Adeleye T.M., ${ }^{2}$ Oyeyipo F.M. and \\ ${ }^{3}$ Adebiyi G. E.
}

${ }^{1}$ Department of Microbiology, Federal University of Agriculture, Abeokuta. Nigeria . ${ }^{2}$ Department of Microbiology, Olabisi Onabanjo University, Ago iwoye, Nigeria ${ }^{3}$ Mycotoxin Laboratory, National Agency for Food Drug Administration and Control (NAFDAC) Oshodi Lagos, Nigeria

\begin{abstract}
Fungi constitute a major problem in the production, storage and processing of agricultural products, recent concern about the consumption of stale retail pepper in Abeokuta necessitated the need to determine the fungal population and also to quantify Aflatoxin produced by the fungi. Fungi species were isolated from 20 pepper samples (Capsicum annum) bought from different markets in Abeokuta using standard microbiological procedures and High Performance Liquid Chromatography (HPLC) was used to quantify the aflatoxin present. Isolated fungi were Aspergillus flavus (55\%), Mucor sp (10\%), Sacharomyces cerevisiae (20\%), Aspergillus fumigatus, Rhizopus sp and Penicillium sp (5\%) respectively. Results shows that fourteen of the pepper samples had no detectable aflatoxin and the aflatoxin content in the remaining six samples was $23 \mathrm{ng} / \mathrm{kg}, 18 \mathrm{ng} / \mathrm{kg}, 15 \mathrm{ng} / \mathrm{kg}, 9 \mathrm{ng} / \mathrm{kg}, 6 \mathrm{ng} / \mathrm{kg}$ and $2 \mathrm{ng} / \mathrm{kg}$, five of these samples had aflatoxin content above the European Union maximum tolerance level of $5 \mathrm{ng} / \mathrm{kg}$. The presence of toxin producing Aspergillus flavus capable of causing food poisoning raises concern over public health risks that may be associated with the consumption of stale pepper.
\end{abstract}

Keywords: Aflatoxin, Fungal contamination, Capsicum annum, stale foods, High Performance Liquid chromatography, public health

Corresponding author Email:oni_eniola51@yahoo.com :Tel.+2348032237108

\section{Introduction}

Pepper (Capsicum annum) is considered the most known and nutritive legume. It is rich in nutrients and can be used as a spice and as colorant due to its colour properties (Mueller et al., 2010). It is usually abundant in the month of August-September. Spoilage is the change in which the food tends to become less palatable with bad smell, appearance or texture (Akinmusire 2011). Stale pepper are fruits that have lost some of their quantity and quality attributes such as size, appearance, shape, texture, moisture content, nutritional value and may not be safe for consumption depending on the degree of their deterioration. Stale pepper, in local areas in
Nigeria are called "Esa". Retailers of peppers sort out and sell these rotten pepper at cheap rates.

Microbial spoilage of food is a limiting factor for shelf life of fruit (Akinmusire, 2011). In order to keep fruits and vegetables from losing their turgidity, farmers or marketers often times sprinkle water on them after harvesting and the low temperature condition encourages the growth of microorganisms and this cause vegetable and fruits to spoil if not sold immediately (Murray et al., 2017). Fruits including pepper are known to undergo selfdisintegration known as autolysis, which leads to softening and results in loss of weight, colour, flavor changes and reduced nutritional 
value (Bhattacharya et al., 2010). Pepper contains a variety of microorganisms on their surfaces, this is not surprising since microbes are ubiquitous (Manonmani et al., 2005). Spoilage of pepper by fungi can lead to mycotoxin contamination which pose high health risk to the consumers.

Aflatoxins negatively impact agricultural produce in all parts of the globe and their accumulation in food and feed represent a major threat to human and animal health (Oluwafemi and Taiwo, 2004). Aflatoxins are poisonous secondary metabolites produced mainly by Aspergillus flavus, $A$. parasiticus and A.nomius. The four major aflatoxins, B1, B2, G1and G2 are the most important mycotoxins in foods and feeds because of their high prevalence in nature and toxicity (Makun et al., 2012).

There is dearth of information on fungi associated with pepper spoilage in Nigeria according to Wogu and Ofuase (2014). This study thus aimed to assess the safety of consumption of stale retail pepper by determining the mycoflora present in the pepper and quantify the aflatoxins if present.

\section{Materials and Methods \\ Collection of Samples}

Twenty stale pepper samples were purchased from different markets in Abeokuta, Nigeria. The samples were collected into sterile polythene bags and transported to the laboratory for analysis.

\section{Preparation of Pepper Sample}

Stale pepper samples were first sterilized by washing under running tap water in order to remove sand and surface dirt. A part of the stale portion of the samples from each market was excised and crushed into paste form using sterile mortar and pestle.

\section{Isolation of Fungi in the Stale Pepper}

Pour plate method was used to enumerate fungal load of the samples. Serial diction of each pepper sample was obtained by pipetting of pepper paste into a test tube containing $9 \mathrm{ml}$ of peptone water and $1 \mathrm{ml}$ was pipetted again from the $10 \mathrm{ml}$ that was made up to another test tube containing $9 \mathrm{ml}$ of peptone water and was done in 10 folds. The $10^{3}-10^{3}$ dilutions were plated on Sabouraud Dextrose Agar (SDA) at $28^{\circ} \mathrm{C}$ in an incubator for five days each dilution was replicable five times, colonies were counted and expressed in colony forming unit/gram (CFU/g) of samples.
Isolates were identified using morphological and cultural characteristics as highlighted by Klich (2002).

\section{Screening for aflatoxigenic Potential of fungal isolates}

Isolates were screened using Bright Greenish-Yellow Fluorescence experiment (BGYF).Strains were inoculated at a central point on a $6 \mathrm{~cm}$ diameter Petri dish containing $10 \mathrm{ml}$ of Coconut Agar Medium (CAM) supplemented with $0.3 \% \beta$-cyclodextrin for a preliminary screening of aflatoxins production, (Fente et al., 2001) and incubated for 5 days in the dark at $28^{\circ} \mathrm{C}$. Cultures were tested for $365 \mathrm{~nm}$ UV light fluorescence and for bright green-yellow colony reverse coloring expression under daylight. 


\section{Results}

Table 1: Identification of fungal isolates in spoilt pepper samples

\begin{tabular}{|c|c|c|c|c|}
\hline $\mathbf{S} / \mathbf{N}$ & Isolates Code & Macroscopy & Microscopy & $\begin{array}{l}\text { Suspected } \\
\text { microorganisms }\end{array}$ \\
\hline 1 & M1 & Brown filamentors colonies & $\begin{array}{l}\text { Smooth walled } \\
\text { condiosphores }\end{array}$ & A fumigatus \\
\hline 2 & M2 & Creamy large white colonies & Conidiphores & $\begin{array}{l}\text { Sacharomyces } \\
\text { cerevisiae }\end{array}$ \\
\hline 3 & M3 & Creamy white colonies & Budding yeast cell & $\begin{array}{l}\text { Sacharomyces } \\
\text { cerevisiae }\end{array}$ \\
\hline 4 & M3 & Creamy white colonies & Budding yeast cell & $\begin{array}{l}\text { Sacharomyces } \\
\text { cerevisiae }\end{array}$ \\
\hline 5 & M4 & White cotton like colonies & $\begin{array}{l}\text { Hyphae without } \\
\text { rhizoid spp }\end{array}$ & Mucor spp \\
\hline 6 & M5 & $\begin{array}{l}\text { Yellowish Filaments } \\
\text { Colonies }\end{array}$ & $\begin{array}{l}\text { Glohose } \\
\text { Conidiophores }\end{array}$ & $\begin{array}{l}\text { Aspergillus } \\
\text { flavus }\end{array}$ \\
\hline 7 & M5 & $\begin{array}{l}\text { Yellowish Filaments } \\
\text { Colonies }\end{array}$ & $\begin{array}{l}\text { Glohose } \\
\text { conidiophores }\end{array}$ & $\begin{array}{l}\text { Aspergillus } \\
\text { flavus }\end{array}$ \\
\hline 8 & M6 & Filamentous creamy & $\begin{array}{l}\text { Large } \\
\text { conidiphores }\end{array}$ & Penicillium \\
\hline 9 & M6 & $\begin{array}{l}\text { Yellowish Filaments } \\
\text { Colonies }\end{array}$ & $\begin{array}{l}\text { Glohose } \\
\text { conidiophores }\end{array}$ & $\begin{array}{l}\text { Aspergilus } \\
\text { flavus }\end{array}$ \\
\hline 10 & M8 & $\begin{array}{l}\text { Yellowish Filaments } \\
\text { Colonies }\end{array}$ & $\begin{array}{l}\text { Glohose } \\
\text { conidiophores }\end{array}$ & Aspergillus flavus \\
\hline 11 & M9 & Creamy white colonies & $\begin{array}{l}\text { Scudding yeast } \\
\text { cell }\end{array}$ & $\begin{array}{l}\text { Sacharomyces } \\
\text { cerevisiae }\end{array}$ \\
\hline 12 & M10 & $\begin{array}{l}\text { Yellowish Filaments } \\
\text { Colonies }\end{array}$ & $\begin{array}{l}\text { Globose } \\
\text { conidiosphores }\end{array}$ & Aspergillus flavus \\
\hline 13 & M11 & $\begin{array}{l}\text { Yellowish Filaments } \\
\text { Colonies }\end{array}$ & $\begin{array}{l}\text { Globose } \\
\text { conidiosphores }\end{array}$ & Aspergillus flavus \\
\hline 14 & M14 & Cotton like colonies & Hypha & Rhizopus spp \\
\hline 15 & M15 & White cotton like colonies & $\begin{array}{l}\text { Hyphae without } \\
\text { rhizoid spp }\end{array}$ & Mucor spp \\
\hline
\end{tabular}

Table one Shows the identification of fungal isolates in stale pepper samples. The isolated moulds were characterized with yellow to brown and white filamentous colonies, smooth walled conidiophores to budding yeast cells.

Table 2: percentage of pepper samples containing identified fungal genara

\begin{tabular}{lll}
\hline Fungal isolates & number & Percentage (\%) \\
\hline Apergillus fumigatus & 1 & 5.0 \\
Aspergillus flavus & 11 & 55.0 \\
Sacharomyces cerevisiae & 4 & 20.0 \\
Mucor spp. & 2 & 10.0 \\
Penicillium spp. & 1 & 5.0 \\
Rhizopus spp. & 1 & 5.0 \\
\hline
\end{tabular}

Table two shows Percentage of Pepper samples containing identified fungal genera. It revealed six organisms isolated from pepper samples. Aspergillus flavus has the highest percentage of occurrence with (55\%) followed by Saccharomyces cerevisae (20\%), Mucor spp (10\%) with Penicillium spp, Aspergillus fumigatus and Rhizopus having ( $5 \%$ each). 
Table 3: Aflatoxigenic potentials identified in fungal isolates

\begin{tabular}{lll}
\hline S/N & Fungal isolates & Aflatoxigenic Properties \\
\hline 1 & Aspergillus fumigatus & ++ \\
2 & Sacharomyces cerevisae & - \\
3 & Aspergillus flavus & +++++ \\
4 & Mucor spp & - \\
5 & Rhizopus spp & - \\
6 & Penicillium spp & - \\
\hline
\end{tabular}

Key

$\begin{array}{rr}+=\text { Fluorescence } & +++++=\text { Fluorescence five times } \\ - \text { = Non Fluorescence } & ++=\text { Fluorescence twice }\end{array}$

Table three reveals that out of the six fungi sample, Aspergillus flavus and A. fumigatus are the moulds that shows potential to be aflatoxigenic with $A$. flavus being the predominant. Sacharomyces cerevisae, Mucor spp, Rhizopus spp, and Penicillium spp shows no potential to produce aflatoxins

Table 4: Aflatoxin levels $(\mathrm{ng} / \mathrm{kg})$ in stale retail pepper in Nigeria.

\begin{tabular}{lllllll}
\hline S/N & SAMPLE & AFB1 & AFB2 & AFG1 & AFG2 & TOTAL AF \\
\hline 1 & Sample 1 & 0.002 & 0.000 & 0.000 & 0.000 & 0.002 \\
2 & Sample 2 & 0.000 & 0.000 & 0.000 & 0.000 & 0.000 \\
3 & Sample 3 & 0.000 & 0.000 & 0.000 & 0.000 & 0.000 \\
4 & Sample 4 & 0.000 & 0.000 & 0.000 & 0.000 & 0.000 \\
5 & Sample 5 & 0.009 & 0.000 & 0.000 & 0.000 & 0.009 \\
6 & Sample 6 & 0.005 & 0.000 & 0.000 & 0.001 & 0.006 \\
7 & Sample 7 & 0.000 & 0.000 & 0.000 & 0.000 & 0.000 \\
8 & Sample 8 & 0.013 & 0.000 & 0.000 & 0.002 & 0.015 \\
9 & Sample 9 & 0.000 & 0.000 & 0.000 & 0.000 & 0.000 \\
10 & Sample 10 & 0.008 & 0.000 & 0.000 & 0.000 & 0.008 \\
11 & Sample 11 & 0.023 & 0.000 & 0.000 & 0.000 & 0.023 \\
12 & Sample 12 & 0.000 & 0.000 & 0.000 & 0.000 & 0.000 \\
13 & Sample 13 & 0.000 & 0.000 & 0.000 & 0.000 & 0.000 \\
14 & Sample 14 & 0.000 & 0.000 & 0.000 & 0.000 & 0.000 \\
15 & Sample 15 & 0.000 & 0.000 & 0.000 & 0.000 & 0.000 \\
16 & Sample 16 & 0.000 & 0.000 & 0.000 & 0.000 & 0.000 \\
17 & Sample 17 & 0.000 & 0.000 & 0.000 & 0.000 & 0.000 \\
18 & Sample 18 & 0.000 & 0.000 & 0.000 & 0.000 & 0.000 \\
19 & Sample 19 & 0.000 & 0.000 & 0.000 & 0.000 & 0.000 \\
20 & Sample 20 & 0.000 & 0.000 & 0.000 & 0.000 & 0.000 \\
\hline
\end{tabular}

Pepper samples $2,3,4,7,9,12,13,14,15,16,17,18,19$ and 20 had no detectable aflatoxin while samples $1,5,6,8,10$ and 11 had $0.002,0.009,0.006,0.015,0.008$ and $0.023(\mathrm{ng} / \mathrm{kg})$ aflatoxin respectively.

\section{Discussion}

Due to ubiquity of fungi, it contaminates food by colonizing them at several stages of food chain (Manonmani et al., 2005). This study has demonstrated that the infiltration of human pathogens into pepper can occur and that survival and growth can occur under certain conditions leading to spoilage. Peppers acidic pH also creates good growth condition for yeast and fungi (Korkutata 2015). Occurrence of Rhizopus specie in food samples has been found to cause spoilage of tropical crops and food poisoning (Frazier and Westoff, 2005). 
This study is in agreement with the findings of Arias et al., (2002) who stated Aspergillus specie as the most prevalent fungal in spoilt pepper. Contamination of pepper could be as a result of poor processing method which may involve washing with faecal contaminated water (Frazier and Westoff, 2005). Aflatoxin B1 was the most prevalent of all aflatoxins $(0.060 \mathrm{ng} / \mathrm{Kg})$ in the six positive pepper samples while Aflatoxin G1 was not found in the samples and this is in agreement with the findings of Alam et al., (2010) who reported that amongst all fractions, AFB1 is normally the most predominant in food and feed products. Aflatoxin contamination is a serious problem in tropical countries of the world where relative humidity is very high and temperatures conducive for its growth and production by moulds.

\section{Conclusion}

Human health is often adversely affected by aflatoxins in diets hence, much attention should be given to what we consume. This research therefore recommended that stale pepper consumption should be discouraged. However, this might not always be ensured or possible especially in urban areas due to transport challenges of moving the pepper from the farm to the urban centres or markets. To reduce postharvest losses in pepper, harvesters and handlers should be careful not to store pepper on the floor instead it should be kept in crates to avoid microbial infiltration while damaged pepper should not be sold at all. It is also recommended that market women selling pepper should be enlightened on the dangers of those pepper getting contaminated and possibility of microbial contamination by some toxin producing organisms which may not be inactivated by cooking heat especially aflatoxin which are heat resistant. To overcome global problem of aflatoxin, even though out of the 6 samples that tested positive for aflatoxin in this research, one of the samples was within the European commission standard regulatory limits of $5 \mathrm{ng} / \mathrm{kg}$, while five were above regulatory limit.

It should be well noted that there is no tolerable daily intake for aflatoxin and that there is no threshold at which no harmful effect is observed. It is therefore recommended that regulatory agencies in Nigeria should monitor aflatoxin in pepper

\section{References}

Akinmusire, O. O. (2011). Fungal Species Associated with the spoilage of some edible fruits in Maiduguri Nothern Eastern Nigeria. The Pan Afr. Med. J. 7: 14

Alam, S., Shah, H.U., Magan, N., Qazi, J.I. and Arif, M. (2010).Effects of calcium propionate and water activity on growth and aflatoxins production by Aspergillu sparasiticus. Pakistan J. of Zoo. 42(1): 57-62.

Arias, C. R., Burns, J.K., Fredrick, L.M., Goodrich, R. M., and Parish, E. M., (2002). Yeast species associated with Orange Juices: Appl. \& Env. Microbiol. 15: 44

Bhattacharya, A., Chattopadhyay, A., Mazumdar, D., Chakravarty, A. and Pal, S. (2010). Antioxydant Constituents and Enzyme Activities in Chilli Peppers. Int. J. of Veg. Sc. $16: 201-211$

Ewekeye, T. S., Oke, O.A., Quadri, A. I., Isikalu, A.O., Umenwaniri, M. O. and Durosimi,M. L. (2013).Studies on Post Harvest Deterioration of some fruits and vegetables in selected markets in Lagos State, Nigeria. Amer. J. of Res. Com. 1: 10

Fente, C. A., Ordaz, J. J., Vazquez, B. I., Franco, C. M. and Cepeda, A. 2001 .New additive for cultural media for rapid identfication of aflatoxin producing Aspergillus strains. Appl. Env. Microbiol. 67:4858-4862.

Frazier, W. C. and Westhoff, D. C. (1978). 3rd Edition- Tata McGraw HillPublication Company Ltd, New Delhi Fd Microbiol. pp. 540

Frazier, W. C. and Westhoff. D. C. (2005). McGraw-Hill Publication Company Ltd, New Delhi Fd. Micribiol. pp. 217-240

Frobisher, M. and Hinsdili, R. D. (1994) In: Fundamentals of Microbiology $9^{\text {th }}$ Edition W.S. Sanders Company Philadelphia. Microbiol. of Fds. Pp750-765

Hell K, Gnonlonfin, GJ, Kodjogbe, G, Lamboni, Y, Abdourhamane, I. K. (2009). Mycoflora and occurrence of aflatoxin in dried vegetables in Benin, Mali and Togo,WestAfri. Int. J. Fd Microbiol. 135:99-104

Klich, M.A., 2002. Identification of common Aspergillus species. Central bureauvoors 
chimmel cultures, Utrecht, the Netherlands. 1116

Korkutata, N.F. and Kavaz, A. (2015). A comparative study of Ascorbic Acid and Capsinoid contents in Red Hot Peppers (Capsicum annum L.) Grown in southeastern Anatolia Region. Int. J. of Fd. Ppties. 18: 4

Makun, H.A., Dutton, M.F., Njobeh, P.B., Gbodi, T.A., Ogbadu, G.H. (2012).Aflatoxin Contamination in Foods and Feeds: A Special Focus on Africa In: Prof. AymanAmerEissa (Ed.) 'Trends in Vital. Fd. \& Control Engnr.' ISBN: 978-953-51-0449-0.

Manonmani H.K., Anand, S., Chandrashekar, A. and Rati, E. R. 2005. Detection of aflatoxigenic fungi in selected food commodities by PCR Process Biochem. 40, 2859-2864.

Mueller, M., Hobiger, S. and Jungbauer, A. (2010).Anti-inflammatory activity of extracts from fruits, herbs and spices. Fd. Chem. 22: 987-996

Murray, K., Wu, F., Shi, J., Xue, S. and Warriner, K. (2017). Challenges in the microbiological food safety of fresh produce: Limitations of post harvest washing and the need for alternative interventions. J. of Fd. Qual. \& Saf. 1:289-301

Norris, J. R. and Pettipher, E. G. (1961). Essay in Agricultural and Food Microbiology. A. V. Publishing Connectcut, Chichester. P 227

Oluwafemi, F. and Taiwo, V.O. 2004.Reversal to toxigenic effects of aflatoxin $B_{1}$ on cockerels by alcoholic extract of African nutmeg, Monodoramyristica. J. of the Sci. of Fd. \& Agric. 84:330-340.

Thubo, A., Edelenbos, M., Christensen, L., Sorensen, Thorup-Kristensen, J.K. (2006).

Effect of organic growing systems on sensory quality and chemical compound of tomatoes. LWT-Fd. Sci Tech. 39: 835-843

Udoh, D.J., Ndon, B, A., Asuquo, P.E. and Ndaeyo, N.U.(2005). Crop Production Techniques for the Topics. Concept publications limited, Lagos, Nigeria238-399.

Wogu, M.D. and Ofuase, O.(2014) Microorganisms responsible for the spoilage of tomato fruits, Lycopersicum esculentum, sold in markets in Benin City, Southern Nigeria. Scholars Acad. J. of Biosc. 2(7): 459-466 